\title{
KARAKTERISTIK RANGKAIAN EKIVALEN DIODA BLEND ORGANIK P30T : PCBM
}

\author{
Winda Setya \\ Program Studi Pendidikan Fisika, Jurusan Pendidikan Matematika dan Ilmu Pengetahuan Alam, \\ Fakultas Tarbiyah dan Keguruan Universitas Islam Negeri Sunan Gunung Djati Bandung, \\ Indonesia \\ Email : suratwindasetya@uinsgd.ac.id
}

ABSTRAK

Telah dilakukan penelitian karakteristik rangkaian ekivalen dioda blend organik P30T:PCBM. Pada penelitian ini, lapisan blend P30T:PCBM dideposisikan diantara elektroda transparan indium tin oxide (ITO) dan Al sebagai kontak. Karakteristik arus tegangan dioda dilakukan pada keadaan gelap dan terang. Penentuan parameter kelistrikan dioda ditentukan dengan model rangkaian ekivalen dioda anorganik. Dari hasil kajian, ketebalan lapisan P30T:PCBM berpengaruh pada penurunan hambatan seri dioda dan peningkatan rapat arus saturasi dioda. Hasil ini bermanfaat untuk lebih memahami mekanisme fisis, yang pada gilirannya meningkatkan performa dan pengembangan dioda organik.

Kata kunci: Keterampilan Generik Sains, Solar System Scope, Tata Surya

\begin{abstract}
Has conducted research diode characteristics equivalent circuit of the organic blend P30T: PCBM. In this study, the blend of P30T:PCBM was sandwiched between a transparent indium tin oxide (ITO) electrode and an Al backside contact. The current-voltage characteristic of the diode was measured under the dark and illumination. In order to determine the electrical parameters of the diode, we employed an equivalent circuit model developed originally for inorganic diode. As a result, the series resistance decreases while the reverse saturation current density increases by decreasing the thickness of P3OT:PCBM layer. This result may be useful for improving the performance of developing organic diode.
\end{abstract}

Keywords: organic diode, P3OT, PCBM, equivalent circuit, current-voltage characteristic.

DOI: http://dx.doi.org/10.15575/itlp.v2i2.6568

Received: 23 Maret 2017 ; Accepted: 14 Juni 2017 ; Published: 1 September 2017 


\section{PENDAHULUAN}

Dioda merupakan komponen dasar pada peranti elektronik seperti sel surya dan fotodetektor. Sifat dioda yang paling penting untuk aplikasi sel surya adalah adalah sifat fotokonduktif, yaitu besarnya arus yang dihasilkan saat dioda menyerap foton dari cahaya yang dipaparkan. Ada dua macam dioda menurut bahan aktifnya, yaitu dioda sambungan $\mathrm{p}-\mathrm{n}$ dan dioda Schottky (Winder, 2001)].

Dioda sebagai peranti berbasis semikonduktor pertama kali ditemukan oleh Sir Fleming pada tahun 1904. Tahun 1950-an Germanium (Ge) sebagai semikonduktor anorganik telah banyak digunakan sebagai bahan pembuatan dioda dan tahun 1960-an Silikon (Si) mulai menggantikan germanium karena sifatnya yang lebih stabil pada suhu ruang. Proses pembuatan peranti berbahan dasar Ge dan Si tidak sederhana dan memerlukan biaya yang relaif banyak.

Sementara itu, bahan organik merupakan salah satu alternatif untuk menggantikan Ge dan Si karena mempunyai beberapa kelebihan (Buxton, 2006; Hoppe, 2004; Nunzi, 2002; Spanggaard, 2004; Winder, 2001), antara lain mudah diproses menjadi lapisan misalnya dengan menggunakan spin coating atau vakum eveporasi, produksi skala besar secara kimiawi lebih mudah dibandingkan bahan anorganik sehingga biaya produksi dapat ditekan, koefisien serapan yang relatif tinggi $\left(10^{5} \mathrm{~cm}^{-1}\right)$ sehingga dapat dibuat peranti dengan ketebalan lapisan $<100 \mathrm{~nm}$, lebar celah energi, transport muatan dan sifat lainnya dapat diatur secara kimiawi, struktur kimia dan fungsinya dapat divariasi dengan mudah (polimer, oligomer, dendrimer, organomineral, dye, pigmen, kristal cair , dll).

$\mathrm{z}$ atau bilayer yang tersusun atas lapisanpolimer terkonjugasi dan fullerene $\left(\mathrm{C}_{60}\right)$. Dengan struktur peranti dan bahan tersebut cahaya matahari yang diserap oleh sel surya adalah dalam rentang difusi eksiton heterojunction yang memberikan kontribusi bagi arus listrik yang dihasilkan (Winder, 2001).

Salah satu cara untuk meningkatkan performa peranti adalah dengan membuat struktur campuran jenis $\mathrm{p}$ dan $\mathrm{n}$ dari bahan yang berbeda atau dikenal dengan bulk heterojunction. Dalam bahan semikonduktor organik, istilah yang bertindak sebagai donor merupakan pembawa muatan hole dan bahan organik yang bertindak sebagai akseptor merupakan pembawa muatan elektron. Ketika akseptor maupun donor menyerap foton, maka terbentuklah pasangan elektronhole dengan energi ikat yang disebut eksiton. Melalui cara tersebut daerah disosiasi ditentukan terkait dengan ketebalan lapisan dari suatu peranti yang akan dibuat (Persson, 2004).

Persambungan p-n pada dioda merupakan tempat terjadinya disosiasi eksiton. Dioda organik lapisan tunggal akan membentuk persambungan Schottky dengan salah satu elektroda dan dioda dua lapisan atau bilayer akan membentuk sambungan p-n seperti pada Gambar 1.

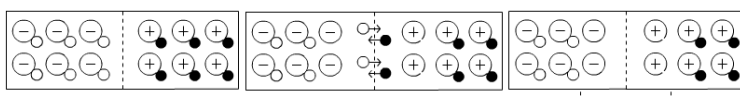

(a)

(b)

(c)

Gambar 1 Proses pembentukan hubungan p$n$, - menyatakan sebuah ion aseptor dan $\bigcirc$ sebuah hole, + menyatakan sebuah ion donor dan - sebuah elektron, $\longleftarrow$ menyatakan medan listrik, (a) hubungan tepat sesudah terbentuk p-n, (b) pembawa berdifusi dan berekombinasi, (c) keadaan setimbang (Rio, 1999).

Bulk heterojunction adalah untuk mentautkan sedekat mungkin campuran komponen donor dan akseptor dalam volume bulk sedemikian sehingga masing-masing antar muka donor dan akseptor berada dalam jarak kurang dari panjang difusi eksiton dari tiap-tiap kedudukan serapan. Skema peranti bulk heterojunction dengan mengabaikan semua jenis pengaturan aras energi dan efek antar muka ditunjukan pada Gambar 2 . Kontak donor mempunyai fungsi kerja yang lebih tinggi dibandingkan fungsi kerja akseptor untuk menghasilkan pengumpulan 
hole dan elektron berturut-turut. Eksiton tergenerasi foto hanya dapat didisosiasikan di dalam lapisan tipis pada heterojunction sehingga peranti menjadi pembatas bagi difusi eksiton. Akibat dari antar muka didispersikan melalui bulk, tidak ada hilang atau loss yang berarti akibat panjang difusi eksiton sangat kecil karena idealnya semua eksiton akan didisosiasikan selama masa hidup eksiton tersebut. Berdasarkan konsepsi tersebut, muatan juga dipisahkan dalam fase yang berbeda dan kemudian rekombinasi direduksi ke tingkat yang besar dan arus foto sering mengkuti intensitas cahaya secara linear atau sedikit sub-linear.

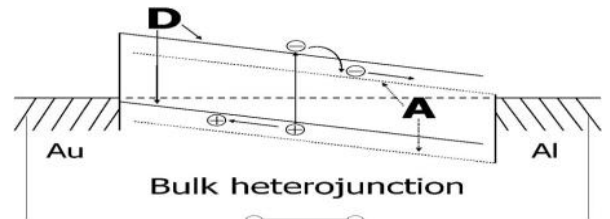

Gambar 2 Struktur peranti bulk heterojunction, D merupakan donor dan A merupakan akseptor (Hoppe, 2004).

Meskipun telah banyak penelitian yang membahas poly (3-octyl thiophene) (P30T) sebagai donor dan (Spanggard, 2004) phenyl $\mathrm{C}_{71}$ butyric acid methyl ester (PCBM) sebagai aseptor, tetapi belum banyak yang melporkan tentang pembuatan dioda dengan struktur blend heterojunction P30T:PCBM dengan perbandingan 1:1 dengan elektroda ITO dan Al. Sifat dioda ditentukan oleh nilai beberapa parameter internalnya. Sayangnya, parameter-parameter tersebut tidak bisa diukur langsung dari eksperimen. Untuk mengatasi hal itu maka model komputasi merupakan cara yang digunakan untuk menentukan besaran fisis dan sifat kelistrikan dioda seperti faktor ideal $(n)$, rapat arus saturasi $\left(U_{s c}\right)$ dan hambatan seri $\left(R_{s}\right)$ sebuah peranti IT0/P30T:PCBM/Al.

Penelitian ini akan dikonsentrasikan untuk fabrikasi dioda lapisan tipis dan karakteristik arus tegangan dioda dengan struktur ITO/P30T:PCBM/Al serta menentukan parameter internal kelistrikan dioda seperti hambatan seri $\left(R_{s}\right)$, rapat arus saturasi dioda $\left(U_{s}\right)$, dan faktor ideal dioda $(n)$.

\section{METODE PENELITIAN}

Bagian metode ditulis dengan panjang 15 - 20\% dari panjang artikel, berisi rancangan penelitian, teknik pengumpulan data dan sumber data serta cara analisis data.

Pada penelitian ini dilakukan fabrikasi dioda blend heterojunction dan perhitungan nilai parameter listrik dari data eksperimen secara numerik. Pembuatannya dimulai dengan pembuatan pola ITO, pembersihan substrat menggunakan ultrasonic cleaner, pembuatan larutan blend P30T:PCBM di spin coating dengan kecepatan $3000 \mathrm{rpm}$ diatas ITO dengan variasi waktu 10 detik, 20 detik dan 30 detik serta perlakuan annel pada variasi waktu 30 detik, dan deposisi $\mathrm{Al}$ menggunakan evaporator sebanyak $50 \mathrm{mg}$ dengan arus $40 \mathrm{~A}$.

Metode yang digunakan untuk mencari parameter internal dengan menggunakan persamaan rangkaian ekivalen yang ditunjukkan pada gambar 3, yaitu :

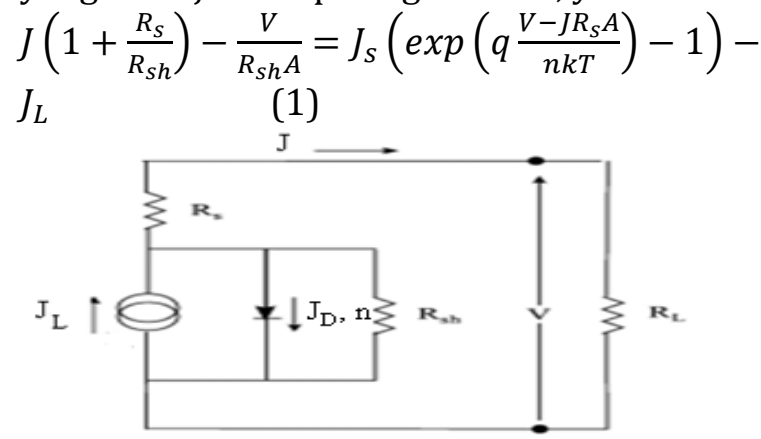

Gambar 3. Rangkaian ekivalen dioda saat diberi cahaya

Penentuan parameter pada keadaan gelap $\left(R_{s}, J_{s}\right.$ dan $\left.n\right)$ dilakukan dengan cara menganggap nilai $R_{s h}=\sim$ dan $J_{L}=0$ sehingga diperoleh persamaan dioda seperti pada persamaan 3.2, yaitu:

$J_{D}=J_{S}\left(\exp \left(q \frac{V-J R_{S} A}{n k T}\right)-1\right)$

Penentuan parameter pada keadaan terang dilakukan dengan menganggap nilai $J_{L}$ $=\left|J_{s c}\right|$. Nilai $J_{s c}$ diperoleh saat $\mathrm{V}=0$ dan $V_{o c}$ diperolah saat $\mathrm{J}=0$ dengan menggunakan metode Newton Rapson. Persamaan untuk $J_{s c}$ dan $V_{o c}$ adalah:

$V_{o c}=\frac{n k_{b} T}{q} \ln \left(1+\frac{J_{L}}{J_{s}}\left[1-\frac{V_{o c}}{J_{L} R_{p} A}\right]\right)$ 
$J_{S c}=\frac{1}{1+\frac{R_{S}}{R_{p}}}\left[J_{L}-J_{S}\left[\exp \left(\frac{J_{S c} R_{S} A}{\frac{n k_{b} T}{q}}\right)-1\right]\right]$

substitusi persamaan 4.4 ke persamaan 4.3 diperoleh:

$1+R_{S} A\left(1-\exp \left[\frac{V_{o c}}{\frac{n k_{b} T}{q}}\right]+\frac{J_{S}}{V_{o c}}\right)+$

$\frac{1}{J_{s c}}\left(J_{L}-J_{S}\left[\exp \left(\frac{J_{s c} R_{S} A}{\frac{n k_{b} T}{q}}\right)-1\right]\right)=0$

Nilai $R_{p}$ diperoleh dari persamaan 4.3 dan nilai $R_{s}$ diperoleh dengan menggunakan metode Newton Raphson pada persamaan 4.5 .

Simpangan minimum sebagai koreksi dari nilai parameter dioda adalah

$S=\sum_{i=1}^{k} J_{S}\left(\exp \left(q \frac{V_{i}-J_{i} R_{S} A}{n k T}\right)-1\right)-J_{L}+$

$\frac{V_{i}}{R_{s h} A}-J_{i}\left(1+\frac{R_{S}}{R_{s h}}\right)$

dengan $J_{i}$ dan $V_{i}$ adalah rapat arus dan tegangan yang diperoleh dari data eksperimen dan $\mathrm{k}$ adalah jumlah data karakterisasi arus tegangan.

\section{HASIL DAN PEMBAHASAN}

Pada penelitian ini dilakukan fabrikasi dioda blend heterojunction dan perhitungan nilai parameter listrik dari data eksperimen secara numerik.

Karakterisasi arus tegangan merupakan salah satu cara untuk mengetahui sifat kontak dari suatu bahan. Kontak antara semikonduktor dan elektroda sebagai penghubung dengan peranti lainnya mempengaruhi kinerja peranti semikonduktor. Pada penelitian ini digunakan ITO sebagai kontak bawah dan Al sebagai kontak atas. Keduanya dipilih karena mempunyai selisih aras Fermi yang cukup besar.

Posisi LUMO dan HOMO untuk P30T adalah 2,8 eV dan 5,05 eV dan PCBM adalah 3,7 eV dan 6,1 eV. P30T sebagai semikonduktor tipe-p memiliki posisi aras Fermi dekat dengan HOMO dan PCBM sebagai semikonduktor tipe-n memiliki aras Fermi dekat dengan LOMO. ITO mempunyai fungsi kerja sebesar 4,83 eV dan Al 4,26 eV. Selisih energi Fermi ITO/P30T sebesar 0,22 eV dan
PCBM/Al sebesar 0,56 eV.

Karkterisasi I-V dilakukan dalam keadaan gelap menggunakan I-V meter. Dioda diberi tegangan dari $0-2 \mathrm{~V}$ untuk bias maju dan bias mundur. Pencatatan arus dilakukan setiap kelipatan $0,05 \mathrm{~V}$ pada tegangan. Bias maju terjadi pada waktu ITO diberi tegangan positif dan Al diberi tegangan negatif. Ketika diberi tegangan positif pada ITO, terjadi penurunan potensial penghalang yang mengakibatkan elektron akan mengalir dari semikonduktor ke logam dan arus yang mengalir akan semakin besar. Sebaliknya jika diberi bias mundur maka akan terjadi peningkatan potensial penghalang yang mengakibatkan arus yang mengalir semakin kecil.

Arus yang mengalir saat diberi bias maju memiliki nilai yang jauh lebih besar daripada arus pada panjar mundur, sehingga peranti ini mempunyai karakteristik sebagai dioda. Arus pada pada saat diberi bias mundur mempunyai nilai hampir nol, tetapi arus meningkat saat diberi tegangan lebih dari -1 sehinga memungkinkan terjadinya tegangan dadal (breakdown). Hasil karakterisasi pada tegangan versus arus pada dioda ITO/P30T:PCBM/Al ditunjukkan pada Gambar 4 .

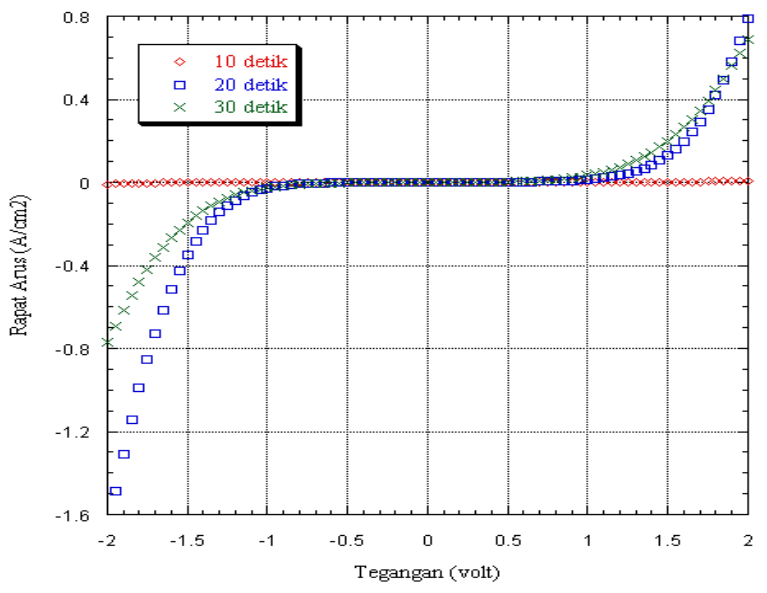

Gambar 4 Grafik karakterik rapat arustegangan pada keadaan gelap dengan variasi lama spin coating 10 detik, 20 detik, dan 30 detik

Dengan menggunakan data eksperimen karakterisasi $\mathrm{I}-\mathrm{V}$, parameter-parameter internal listrik dengan iterasi $R_{s}, J_{s}$ dan $n$ 
dapat ditentukan. Grafik pencocokan kurva dengan iterasi $R_{s}$ dan $J_{s}$ ditunjukkan pada Gambar 5, Gambar 6, Gambar 7. Secara grafis pengukuran $J-V$ dan $R_{S}$ menentukan kelengkungan kurva yang akan mempengaruhi kinerja sel surya karena berkaitan erat dengan efisiensi daya. Sel surya akan memiliki efisiensi yang tinggi jika nilai $R_{s}$ kecil dan nilai $R_{s h}$ sangat besar.

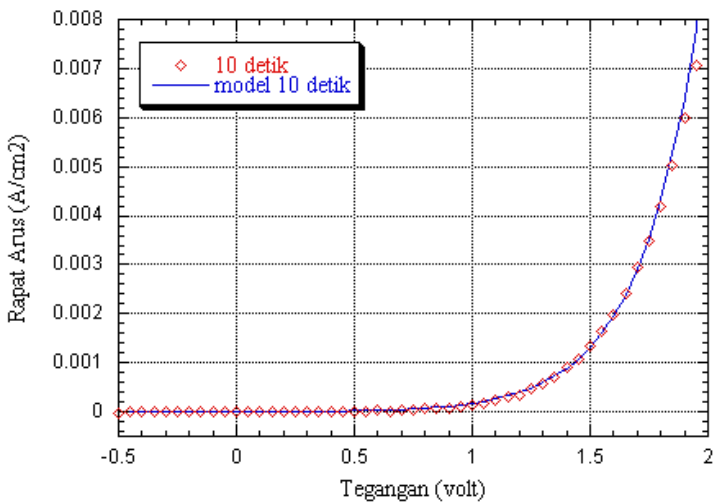

Gambar 5 Kurva J-V ITO/P30T:PCBM/Al dengan lama spin coating 10 detik

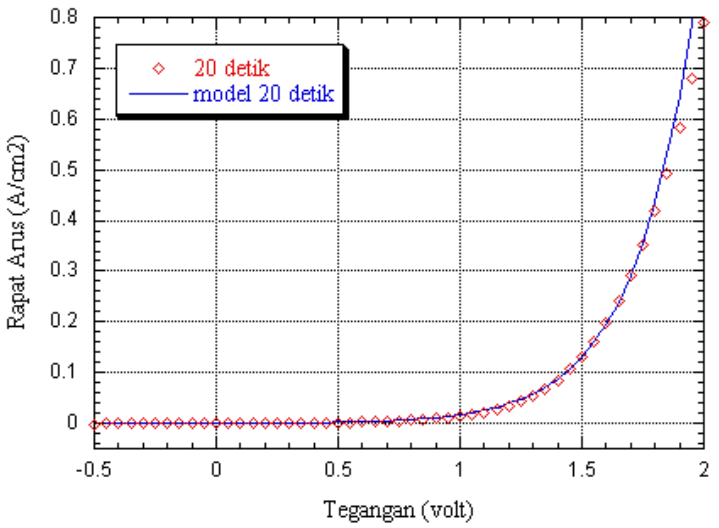

Gambar 6 Kurva J-V ITO/P30T:PCBM/Al dengan lama spin coating 20 detik

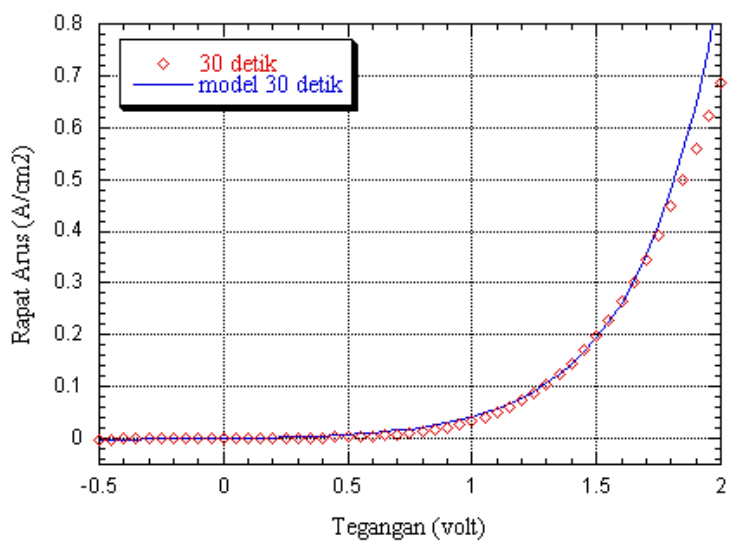

Gambar 7 Kurva J-V ITO/P30T:PCBM/Al dengan lama spin coating 30 detik

Hasil dari perhitungan parameter internal dioda ditunjukkan pada Tabel 1.

Tabel 1 Nilai parameter dioda organik secara numerik

\begin{tabular}{|c|c|c|c|}
\hline Perlakuan & $\mathrm{n}$ & $\mathrm{J}_{\mathrm{s}}\left(\mathrm{A} / \mathrm{cm}^{2}\right)$ & $\mathrm{R}_{\mathrm{S}}(\Omega)$ \\
\hline S10 & 15 & $3,5 \times 10^{-6}$ & 62036, \\
\hline S20 & 1,5 & $327,3 \times 10^{-6}$ & 0 \\
\hline s 30 & 1,5 & 2229,7 & 642,6 \\
\hline 530 & 1,5 & $10^{-6}$ & 622,7 \\
\hline
\end{tabular}

S10 adalah proses spin coating selama 10 detik, S20 adalah proses spin coating selama 20 detik, dan S30 adalah proses spin coating selama 30 detik. Berdasarkan tabel 5.1, ketebalan lapisan blend P30T:PCBM berpengaruh terhadap penurunan nilai hambatan seri.

Ketebalan lapisan dioda dengan cara memvariasi lama spn coating sangat berpengaruh pada penurunan nilai $R_{s}$. Besarnya nilai $R_{s}$ pada eksperimen disebabkan oleh faktor koreksi yang tidak diperhitungkan dan akan berpengaruh pada kemiringan kurva saan $V_{o c}$. Nilai $R_{s}$ akan menentukan kelengkungan kurva. Dalam dioda organik, nilai $R_{s}$ akan mempengaruhi besarnya efisiensi daya saat dioda diberi penyinaran atau dalan sel surya. Nilai $n$ akan mempengaruhi besarnya nilai $J_{s}$.

Lapisan ITO/P30T:PCBM/Al dengan lama spincoating 30 detik mempunyai nilai hambatan yang kecil $R_{s}=622,7 \Omega$, tetapi nilai $J_{s}=2229,7 \times 10^{-6}$.

\section{PENUTUP}

Pada penelitian ini telah berhasil dikarakterisasi diode organik ITO/P3OT:PCBM/Al yang dibuat dengan variasi lama spin coating larutan blend P30T:PCBM yakni selama 10 detik, 20 detik dan 30 detik. Hasil $J-V$ dioda blend organik struktur ITO/P30T:PCBM/Al menunjukkan karakteristik diode dengan lama spincoating 30 detik mempunyai nilai hambatan seri sebesar $R_{s}=622,7 \Omega$.

\section{UCAPAN TERIMAKASIH}


Terima kasih kepada Dr. Kuwat Triyana, Jurusan Fisika UGM yang telah membimbing penelitian ini.

\section{REFERENSI}

Buxton, G. A., Clarke, N., 2006, Computer Simulation of Polymer Solar Cells, Modelling Simul. Mater. Sci. Eng. 15, pp. 13-26.

Hoppe, H., Arnold, N., Meissner, D., dan Sariciftci, N. S., 2004, Modelling of Optical Absorbtion in Conjugated Polymer/Fullerene Bulk Heterojunction Plastic Solar Cells, Thin Solid Films 19, No. 7, pp.589-592.

Nunzi, J. M., 2002, Organic Photovoltaic Material and Devices, C. R. Physique 3, pp.523-542.

Persson, N. K., Schubert, M., Inganas O., 2004, Optical Modelling of a Layered Photovoltaic Device with a Polyfluorene Derivative/Fullerene as The Active Layer, Solar Energy Materials \& Solar Cells 83, pp.169-186.

Rio, R., dan Iida, M., 1999, Fisika dan Teknologi Semikonduktor, PT Pradnya Paramita, Jakarta.

Spanggaard, H. dan Krebs, F. C., 2004, A Brief History of The Development of Organic and Polymeric Photovoltaic, Solar Energy Materials and Solar Cell 83, pp.125-146.

Sze, S.M., 1981, Physics of Semiconductor Devices 2nd edition, John Wiley and Sons.

Winder, C., 2001, Sensitization of Low Bandgap Polymer Bulk Heterojunction Solar Cells, Thesis Graduate School of Linz University. 